\title{
Kemampuan hidrogel komposit berbasis produk samping industri penyamakan kulit dalam menyerap air dan larutan garam
}

\section{The ability of composite hydrogel based on by-product of leather tanning industry to absorb water and salt solutions}

\author{
Sugihartono*, Dona Rahmawati, Ageng Priatni \\ Balai Besar Kulit, Karet dan Plastik, Jl. Sokonandi No. 9, Yogyakarta 55166, Indonesia \\ * Penulis korespondensi. Tel.: +62 274 512929, 563939; Faks.: +62 274563655 \\ E-mail: hsugihartono@ymail.com
}

Diterima: 6 April $2020 \quad$ Direvisi: 30 Mei $2020 \quad$ Disetujui: 8 Juni 2020

\begin{abstract}
The study aimed to explore the ability of composite hydrogels based on the leather tanning by-product to absorb water and salt solutions. Gelatin, from pickled sheep skin trimming, as a basic ingredient of the composite hydrogels was processed in alkaline condition. Composite hydrogels were made with 6 (six) variations of treatment. The effect of methylene-bis-acrylamide and kaolin was observed based on swelling properties. The absorption of water and salt solution from the hydrogel with methylene-bis-acrylamide $0.6 \mathrm{~g}$ treatment was lower than methylene bisacrylamide with $1.0 \mathrm{~g}$ treatment. Water absorption increased by $8 \mathrm{~g}$ kaolin addition then decreased with subsequent additions. The highest absorption of water and salt solution from composite hydrogel were $26.29 \mathrm{~g} / \mathrm{g}$ and 10.97 $\mathrm{g} / \mathrm{g}$, respectively, from $1 \mathrm{~g}$ of methylene-bis-acrylamide and $8 \mathrm{~g}$ of kaolin. The results of FTIR measurement showed cross-graft reaction between gelatin-g-acrylic acid and kaolin that marked by the shifting of several absorption peaks.
\end{abstract}

Keywords: acrylic acid, composite material, gelatin, hydrogel, kaolin.

\begin{abstract}
ABSTRAK
Penelitian ini bertujuan untuk mengetahui kemampuan hidrogel komposit berbasis produk samping industri penyamakan kulit dalam menyerap air dan larutan garam. Gelatin, dari potongan kulit pikel domba, sebagai bahan dasar hidrogel komposit diproses secara basa. Hidrogel komposit dibuat dengan enam variasi perlakuan. Pengaruh methylene-bis-acrylamide dan kaolin diamati berdasarkan swelling property. Daya serap terhadap air dan larutan garam dari hidrogel perlakuan methylene-bis-acrylamide 0,6 g lebih rendah dari perlakuan methylene-bisacrylamide 1,0 g. Daya serap air hidrogel juga dipengaruhi oleh jumlah kaolin yang ditambahkan. Daya serap air meningkat pada penambahan kaolin sebanyak $8 \mathrm{~g}$, kemudian menurun pada penambahan berikutnya. Daya serap terhadap air dan larutan garam dari hidrogel komposit yang tertinggi masing-masing adalah 26,29 g/g dan 10,97 $\mathrm{g} / \mathrm{g}$ diperoleh dari perlakuan methylene-bis-acrylamide $1,0 \mathrm{~g}$ dan kaolin $8 \mathrm{~g}$. Hasil pengukuran FTIR menunjukkan telah terjadi reaksi cangkok silang antara gelatin-g-asam akrilat dan kaolin yang ditandai bergesernya beberapa puncak serapan.
\end{abstract}

Kata kunci: asam akrilat, gelatin, hidrogel, kaolin, komposit.

\section{PENDAHULUAN}

Hidrogel mempunyai sifat dapat menyerap air atau larutan serta dapat melepaskannya secara terkendali. Aplikasi hidrogel digolongkan menjadi 2 (dua), yaitu penggunaan higienis dan non higienis (Zohuriaan-Mehr et al., 2010) antara lain sebagai bahan adsorpsi atau imobilisasi ion uranil dari larutan (Chauhan \& Chauhan, 2010), rekayasa biomedis (Li et al., 2012), bahan adsorben untuk menghilangkan polutan organik 
dan inorganik dalam air (Jing et al., 2013), sebagai media tumbuh dalam pertanian (tanaman hias) (Anah \& Astrini, 2015), serta sebagai bahan untuk mengatasi limbah pewarna dan krom (Cr(VI)) di industri (Khan \& Lo, 2017). Hidrogel dapat dibuat dengan menggunakan bahan monomer sintetis seperti asam akrilat, akrilonitril, akrilamid, dan asam metakrilat, yang dimodifikasi dengan polimer alam seperti pati, selulosa dan turunannya (Sadeghi \& Heidari, 2011), serta khitosan (Novi et al., 2016). Kemampuan menyerap air dan sifat hidrogel antara lain ditentukan oleh jenis bahan penyusunnya dan derajat ikatan silangnya (Nasir, 2010).

Limbah padat belum tersamak berupa skin trimming dari industri penyamakan kulit mengandung protein yang dapat digunakan kembali (reusable) sebagai bahan lem, gelatin, pakan ternak, dan lain-lain (Fathima et al., 2012) atau dikategorikan sebagai produk samping yang bermanfaat sebagai bahan dasar untuk industri lain. Skin trimming merupakan produk samping proses beamhouse, yang berjumlah 5-7\% dari keseluruhan limbah kulit (Zafar, 2012). Hidrolisis parsial dari skin trimming, menggunakan asam atau basa, akan menghasilkan gelatin. Gelatin yang dihasilkan dapat dimanfaatkan untuk industri pangan serta berbagai keperluan industri lainnya (IULTCS, 2018).

Gelatin secara bertahap dapat menyerap air sebanyak 5 sampai 10 kali berat aslinya (Suryani et al., 2009), merupakan bahan renewable resource yang bersifat biokompatibel, biodegradable, dan dapat digunakan sebagai bahan biomaterial (Dian et al., 2012). Gelatin bersifat mudah larut dalam air, transparan, tidak berwarna, tidak berbau, tidak berasa, dan tidak beracun (Jakhar et al., 2012). Biosorben berupa gelatin yang terbuat dari skin trimming kulit domba pikel (kulit belum tersamak) lebih efisien karena memanfaatkan limbah padat dan ketersediannya melimpah. Salah satu cara untuk meningkatkan daya serap air gelatin adalah dengan mencangkok silang (grafting) dengan bahan polimer sintetis. Polimer alami seperti selulosa telah berhasil di cangkok-silang secara kimia dengan monomer akrilamid menggunakan inisiator dan cross-link agent (Khasanah, 2013). Kopolimerisasi cangkok-silang gelatin (sebagai backbone) dapat dilakukan dengan penambahan asam akrilat atau akrilamida, menggunakan inisiator ammonium persulfat (Soleimani et al., 2012). Baek et al. (2015) melakukan grafting kolagen secara kimia dengan poliakrilamid menggunakan inisiator dan cross-link agent.

Pembuatan hidrogel komposit melalui penambahan silika, tanah liat, dan lainnya dapat memperbaiki sifat mekanik, daya serap air, dan menurunkan biaya produksi. Beberapa peneliti telah membuat absorben polimer hidrogel komposit mengunakan bahan anorganik seperti vermiculite, celite, dan bentonite. Parparita et al. (2014) menggunakan bahan anorganik montmorillonite, polivinil alkohol, khitosan, inisiator, dan cross-link agent untuk membuat hidrogel. Verma et al. (2017) membuat hidrogel dengan menggunakan bahan anorganik nano clay, asam akrilat, akrilamida, inisiator, dan crosslink agent. Hidrogel yang dihasilkan dari bahan sintetis bersifat sulit terurai di alam dan dapat menimbulkan iritasi pada kulit apabila digunakan untuk kesehatan (popok dan pembalut wanita). Gelatin bersifat aman, tidak menimbulkan iritasi pada kulit dan lebih mudah terurai di alam. Penggunaan gelatin sebagai bahan hidrogel akan mampu mengatasi kelemahan hidrogel dari bahan sintetis. Penelitian ini bertujuan untuk mengetahui daya serap air dan larutan garam hidrogel komposit yang berbasis produk samping industri penyamakan kulit. Grafting gelatin dengan asam akrilat, dilakukan secara kimia menggunakan inisiator dan cross-link agent serta kaolin sebagai komposit.

\section{BAHAN DAN METODE Bahan Penelitian}

Bahan penelitian adalah trimming kulit pikel domba dari PT. Budi Makmur Jaya Murni, Yogyakarta, asam akrilat (Sigma Aldrich), kalium persulfat p.a., kaolin (Takehara Kagaku Kogyo Co. Ltd.), natrium hidroksida $(\mathrm{NaOH})$ dari Bratachem, Yogyakarta, NN-methylene-bis-akrilamid (MBA) (Sigma Aldrich), hidrogen peroksida $\left(\mathrm{H}_{2} \mathrm{O}_{2}\right)$ dari Bratachem Yogyakarta, dan sejumlah bahan untuk uji karakterisasi absorben hidrogel.

\section{Peralatan Penelitian}

Peralatan yang digunakan pada penelitian ini terdiri atas oven merek Memmert U 30780682 , penangas air (waterbath) merek Memmert W 760 $\mathrm{R}$, pengaduk elektris merek IKA, $\mathrm{pH}$ meter merek Mettler Toledo Seven Easy N 315, dan timbangan digital merek Mettler Toledo AB204-S. Peralatan lainnya adalah gelas piala, gelas ukur, kompor listrik, labu ukur, magnetic stirrer, nampan plastik, 
pipet ukur, serta kain saring 100 mesh.

\section{Metode Penelitian}

Metode yang digunakan untuk pembuatan absorben polimer hidrogel komposit berbasis gelatin dari produk samping industri penyamakan kulit (IPK) dilakukan secara bertahap yaitu, tahap pembuatan gelatin dari trimming kulit pikel IPK, tahap preparasi kaolin, dan tahap pembuatan hidrogel komposit.

Proses pengolahan gelatin dari trimming kulit pikel domba dilakukan menggunakan metode Rahmawati et al. (2016) yang dimodifikasi. Mula-mula trimming kulit pikel dicuci dengan air sampai $\mathrm{pH}$ air bekas cucian netral. Selanjutnya ditiriskan, diperkecil ukurannya $\pm 1,5 \times 1,5 \mathrm{~cm}$ dan dikeringkan. Kulit pikel, yang telah kering, dihidrolisa secara parsial menggunakan $\mathrm{NaOH}$ 2\% (b/v) (1 bagian kulit : 10 bagian larutan $\mathrm{NaOH})$ selama 24 jam. Kemudian, kulit pikel dicuci sampai $\mathrm{pH}$ air cucian mencapai 6,5-7,5. Ekstraksi gelatin dilakukan dengan menggunakan air (1 bagian kulit terhidrolisa : 5 bagian air) pada suhu $70-80{ }^{\circ} \mathrm{C}$ dalam penangas air selama 3 jam. Selanjutnya filtrat dipisahkan dengan penyaringan dan kemudian dikeringkan. Gelatin kering digiling menggunakan blender sampai berbentuk serbuk. Gelatin serbuk siap digunakan untuk pembuatan hidrogel komposit.

Preparasi kaolin mengikuti cara Novi et al. (2016) yang dimodifikasi, dimana kaolin kering sebanyak 50 gram dimasukkan ke dalam gelas bekeryang berisi 1 Laquades, diaduk menggunakan magnetic stirrer selama 3-4 jam, selanjutnya ditambah $30 \mathrm{~mL} \mathrm{H}_{2} \mathrm{O}_{2}$ (hidrogen peroksida) $30 \%$ (untuk menghilangkan pengotor yang berupa zatzat organik). Campuran didiamkan selama 24 jam sampai kaolin mengendap, selanjutnya bagian atas didekantasi. Residu yang dihasilkan, ditambahkan aquades sebanyak $1 \mathrm{~L}$, dan diaduk selama 3-4 jam, lalu didiamkan selama 24 jam. Endapan yang diperoleh disaring dan dikeringkan dalam oven pada suhu $70{ }^{\circ} \mathrm{C}$ sampai kering (selama 4-5 jam). Kaolin yang telah kering digiling dan diayak menggunakan saringan 100 mesh.

Absorben polimer hidrogel komposit yang diteliti dibuat menggunakan metode Nasir (2010) yang dimodifikasi. Gelatin sebanyak 4 gram dilarutkan dalam aquades $200 \mathrm{~mL}$, dipanaskan sampai suhu $70{ }^{\circ} \mathrm{C}$ sambil diaduk menggunakan pengaduk elektris pada kecepatan $300 \mathrm{rpm}$ hingga larut sempurna. Kaolin ditambahkan ke dalam larutan gelatin sesuai perlakuan (Tabel 1) sambil diaduk pada $300 \mathrm{rpm}$ hingga homogen (selama 10 menit). Selanjutnya ditambahkan kalium persulfat sebanyak 1 gram yang telah dilarutkan dalam aquades $10 \mathrm{~mL}$, sambil diaduk dengan kecepatan 300 rpm selama 15 menit. Selanjutnya ditambahkan lagi asam akrilat monomer sebanyak 40 gram yang telah ditambah aquades $40 \mathrm{~mL}$ dan dinetralkan menggunakan larutan $\mathrm{NaOH} 30 \%$ (b/v). Selanjutnya ditambahkan MBA (methylene bis-acrylamide) sesuai perlakuan (Tabel 1) yang telah dilarutkan dalam $5 \mathrm{~mL}$ aquades, sambil diaduk pada putaran $300 \mathrm{rpm}$ selama 90 menit pada suhu $70{ }^{\circ} \mathrm{C}$. Selanjutnya ditambahkan etanol sebanyak $500 \mathrm{~mL}$, didiamkan selama 6 jam. Alkohol didekantasi dan hidrogel komposit, yang diperoleh, dikeringkan dalam oven pada suhu $60{ }^{\circ} \mathrm{C}$ hingga kering. Hidrogel komposit kering dikecilkan ukurannya, dikemas dalam kantong plastik, kemudian disimpan pada suhu ruang untuk selanjutnya dilakukan pengujian.

\section{Karakterisasi}

Uji karakterisasi dilakukan terhadap gelatin dan absorben polimer hidrogel komposit. Karakterisasi gelatin meliputi kadar abu, kadar air, daya serap air (swelling), dan derajat keasaman $(\mathrm{pH})$. Karakterisasi absorben polimer hidrogel komposit meliputi kadar air, kapasitas absorpsi/ daya serap air (swelling), daya serap larutan garam, dan identifikasi gugus fungsi pada absorben polimer hidrogel komposit. Identifikasi gugus fungsi menggunakan Fourier Transform Infrared (FTIR) terhadap absorben polimer hidrogel komposit yang penyerapan airnya paling tinggi.

\section{Uji daya serap air (swelling)}

Pengukuran swelling equilibrium dalam air suling dilakukan untuk menentukan kapasitas penyerapan hidrogel. Daya serap air dinyatakan dalam rasio swelling $\left(\mathrm{S}_{\mathrm{w}}\right)$, didefinisikan dengan persamaan (1),

$$
S w=(W s-W d) / W d
$$

$\mathrm{W}_{\mathrm{s}}=$ berat hidrogel komposit yang bengkak pada kesetimbangan

$\mathrm{W}_{\mathrm{d}}=$ berat hidrogel komposit dalam keadaan kering

Sampel hidrogel komposit direndam dalam sejumlah besar air suling dan kenaikan beratnya 
Tabel 1. Formulasi absorben polimer hidrogel komposit yang diproduksi.

\begin{tabular}{lrrrrrr}
\hline \multirow{2}{*}{ Bahan absorben hidrogel } & \multicolumn{6}{c}{ Percobaan (gram) } \\
\cline { 2 - 7 } & \multicolumn{1}{c}{1} & \multicolumn{1}{c}{4} & \multicolumn{1}{c}{5} & \multicolumn{1}{c}{6} \\
\hline Asam akrilat monomer & 40,0 & 40,0 & 40,0 & 40,0 & 40,0 & 40,0 \\
Kalium persulfat & 1,0 & 1,0 & 1,0 & 1,0 & 1,0 & 1,0 \\
Gelatin & 4,0 & 4,0 & 4,0 & 4,0 & 4,0 & 4,0 \\
N,N-metilen-bis-akrilamid & 0,6 & 0,6 & 0,6 & 1,0 & 1,0 & 1,0 \\
Kaolin & 4,0 & 8,0 & 12,0 & 4,0 & 8,0 & 12,0 \\
\hline
\end{tabular}

dipantau sampai kesetimbangan tercapai yaitu sekitar 24 jam. Sebelum ditimbang, sampel hidrogel yang bengkak dengan lembut dibasahi dengan kertas lunak untuk menghilangkan kelebihan air dari permukaannya.

\section{HASIL DAN PEMBAHASAN \\ Gelatin}

Hasil penelitian menunjukkan bahwa gelatin yang digunakan untuk pembuatan hidrogel komposit memiliki kadar abu 1,07-2,09\%, kadar air 11,70-12,09\%, daya serap air (swelling) 5,53$6,35 \mathrm{~g} / \mathrm{g}$, dan derajat keasaman $(\mathrm{pH})$ 8,2-8,4. Elemen dasar penyusun gelatin adalah karbon $50,5 \%$, hidrogen $6,8 \%$, nitrogen $17,0 \%$, dan oksigen 25,2\% (GMIA, 2019). Gelatin kering biasanya mengandung air sebanyak $8-13 \%$ (GMIA, 2019), dan masih diperbolehkan sampai maksimum 16\% (BSN, 1995). Kadar abu gelatin dibatasi maksimum sebesar 3,25\% (BSN, 1995), oleh GMIA (2019) dibatasi pada kisaran 0,5-2,0\%. Keadaan ini berarti bahwa kadar air dan kadar abu gelatin memenuhi syarat SNI 01-3735-1995 dan GMIA. Gelatin yang diproses menggunakan basa memiliki pH 9,69 $\pm 0,08$ (Mariod \& Fadul, 2013).

\section{Hidrogel \\ Kadar air}

Kadar air suatu bahan dapat digunakan sebagai indikator tingkat kekeringan, bulk density, menentukan bobot, dan tekstur bahan, serta sifat bahan lainnya. Bahan yang memiliki kadar air tinggi biasanya memiliki tekstur yang lebih lunak, sedangkan bahan yang kering cenderung memiliki tekstur yang lebih keras. Bahan yang bersifat higroskopis, apabila didiamkan pada udara terbuka, akan menyerap atau melepaskan air untuk mencapai kesetimbangan dengan lingkungan. Kadar air hidrogel berkisar antara 7,14-9,6\% (Gambar 1). Keadaan ini menunjukkan bahwa kadar air hidrogel komposit dari berbagai perlakuan tidak menunjukkan perbedaan yang cukup berarti.

Dalam Gambar 1 tampak bahwa perlakuan 5 (kaolin $8 \mathrm{~g}$ dan MBA $1 \mathrm{~g}$ ) merupakan perlakuan yang memiliki kandungan air paling rendah. Secara teoritis, hidrogel yang memiliki kandungan air rendah akan memiliki kemampuan penyerapan air yang tinggi apabila dibandingkan dengan hidrogel yang memiliki kandungan air lebih tinggi. Kadar air hidrogel hasil percobaan kesemuanya memenuhi

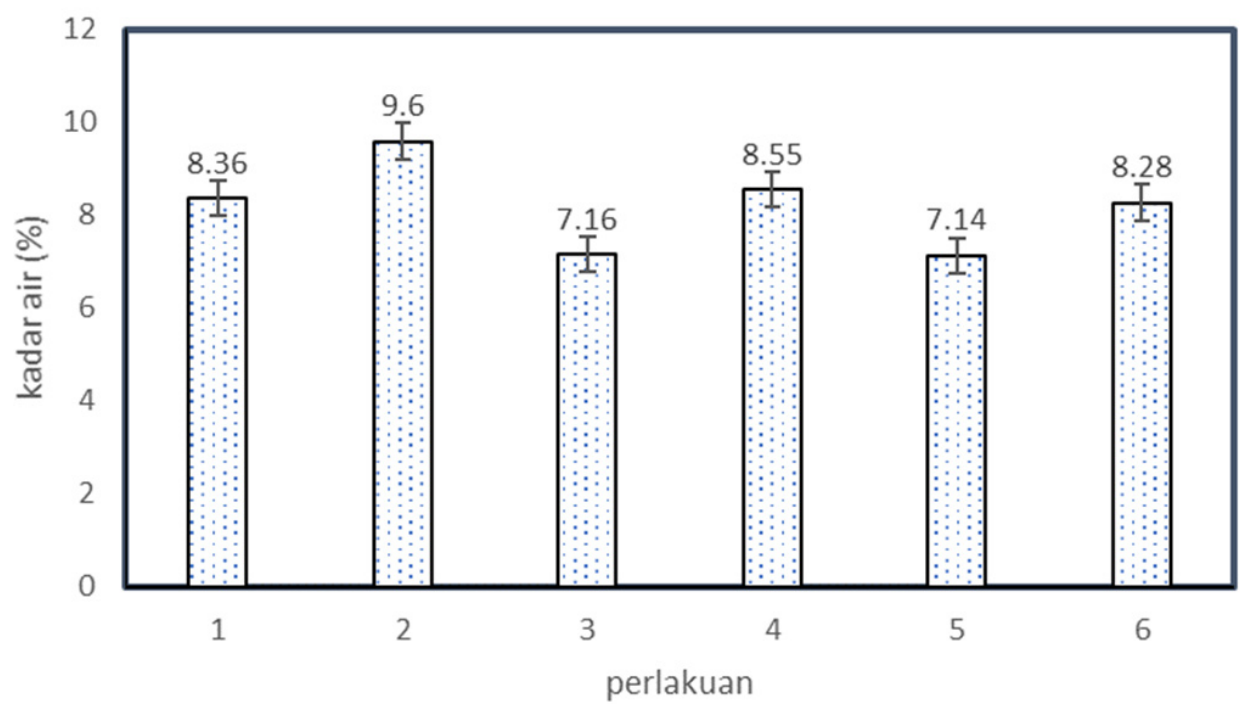

Gambar 1. Kadar air hidrogel komposit. 
persyaratan mutu superabsorbent polymer karena nilainya berada dibawah 20\% (BSN, 2015).

\section{Daya serap air}

Hidrogel bersifat hidrofilik, merupakan polimer yang memiliki ikatan silang tiga dimensi pada jaringan polimernya untuk menyerap dan menahan air dalam jumlah besar. Daya serap air (swelling) hidrogel berkisar antara 9,83-26,28 g/g. Gambar 2 menunjukkan bahwa penggunaan MBA mempengaruhi daya serap air hidrogel komposit yang dihasilkan. Daya serap air hidrogel dari perlakuan MBA 0,6 g lebih rendah dari perlakuan MBA 1,0 g. Astrini et al. (2016) melaporkan bahwa penambahan cross-linker MBA sampai konsentrasi sebesar 3,75\% (b/b) asam akrilat dapat meningkatkan kemampuan kapasitas swelling dari produk hidrogel. Penambahan MBA lebih besar dari konsentrasi tersebut justru menurunkan daya serap air hidrogel.

Sadeghi dan Heidari (2011) menyatakan bahwa penggunaan MBA sebagai cross-link agent berpengaruh terhadap daya serap air hidrogel yang dibuat dari gelatin dengan asam metakrilat. Konsentrasi cross-linker yang tinggi akan mengurangi ruang diantara rantai kopolimer dan menjadikan struktur silang sangat kaku, akibatnya permukaan tidak bisa diperluas dalam mengikat sejumlah besar air. Purba et al. (2018) juga menyatakan bahwa semakin besar jumlah cross- linker, maka dihasilkan hidrogel dengan densitas silang yang semakin tinggi. Gugus fungsional hidrofilik yang melekat pada backbone polimer menjadikan hidrogel mampu menyerap air, sedangkan ikatan cross-link antar network dalam rantai menjadikan hidrogel tidak larut dalam air. Kemampuan hidrogel dalam menyerap air terdeionisasi berkisar antara 10-1000 g/g (Purba et al., 2018).

Peningkatan jumlah kaolin pada hidrogel juga mempengaruhi daya serap air. Jumlah MBA yang sama 0,6 g (perlakuan 1-3) dan MBA $1 \mathrm{~g}$ (perlakuan 4-6) menunjukkan bahwa daya serap air hidrogel komposit mengalami peningkatan sampai pada penambahan kaolin sebanyak $8 \mathrm{~g}$ (perlakuan 2 dan 5), kemudian pada konsentrasi berikutnya justru menurunkan daya serap air hidrogel. Pengaruh kaolin terhadap daya serap air hidrogel komposit mirip dengan MBA, dimana daya serap air mula-mula meningkat sampai batas tertentu kemudian menurun seiring dengan bertambahnya jumlah kaolin pada komponen hidrogel komposit. Konsentrasi kaolin yang tinggi akan menjadikan struktur silang sangat kaku sehingga permukaan absorben tidak bisa diperluas dalam mengikat sejumlah besar air (Sadeghi \& Heidari, 2011). Daya serap air hidrogel komposit yang paling banyak didapat dari perlakuan 5 (kaolin $8 \mathrm{~g}$, MBA $1 \mathrm{~g}$ per $40 \mathrm{~g}$ monomer asam akrilat) yaitu sebesar $26,28 \mathrm{~g} / \mathrm{g}$.

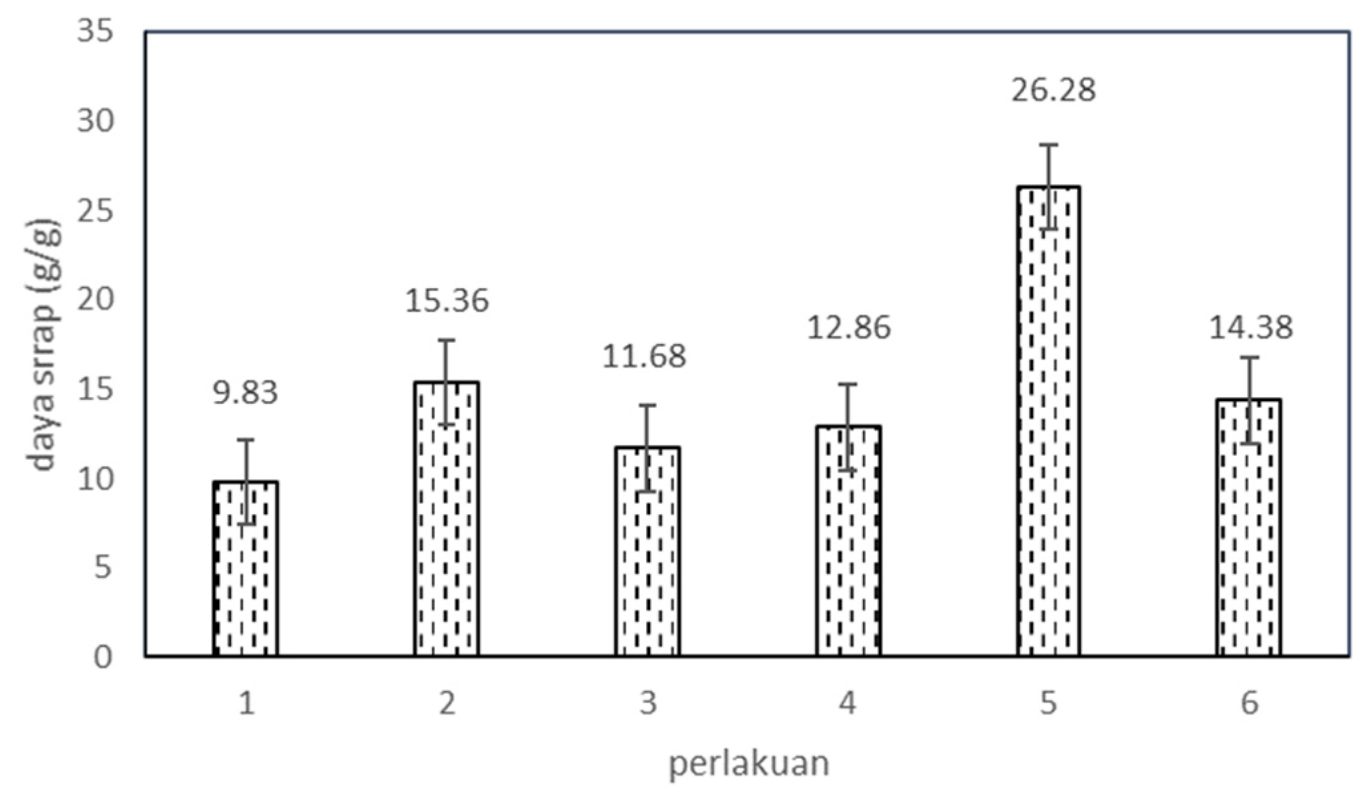

Gambar 2. Pengaruh kaolin dan MBA terhadap daya serap air hidrogel komposit. 


\section{Daya serap larutan garam $\mathrm{NaCl}$ 9\%}

Pengujian daya serap larutan garam diperlukan karena memiliki korelasi kemampuan hidrogel dalam penggunaannya untuk popok bayi, popok dewasa, dan pembalut wanita. Ahmed (2015) menyatakan bahwa salah satu fitur fungsional yang ideal dari hidrogel adalah memiliki kapasitas yang tinggi terhadap penyerapan larutan garam. Daya serap larutan garam $(\mathrm{NaCl} 9 \%)$ oleh hidrogel komposit berkisar antara 6,53-10,97 g/g (Gambar $3)$.

Daya serap larutan garam hidrogel dari perlakuan MBA 1,0 g lebih besar dari perlakuan MBA 0,6 g. Kondisi ini sejalan dengan kemampuan daya serap airnya. Daya serap larutan garam tertinggi diperoleh dari perlakuan 5 (kaolin $8 \mathrm{~g}$ dan MBA $1 \mathrm{~g}$ ) yaitu $10,97 \mathrm{~g} / \mathrm{g}$. Kemampuan penyerapan larutan garam dari hidrogel lebih kecil apabila dibandingkan dengan kemampuan penyerapan airnya. Astrini et al. (2016) juga menyatakan bahwa rasio swelling hidrogel dalam larutan garam lebih kecil apabila dibandingkan dengan rasio swelling hidrogel dalam air.

Larutan garam yang umum digunakan untuk pengujian daya serap air hidrogel adalah larutan garam natrium klorida $(\mathrm{NaCl})$ karena ion-ion garam mempengaruhi daya serap hidrogel terhadap air (Astrini et al., 2016). Tekanan osmosis pada hidrogel dalam larutan garam $\mathrm{NaCl}$ menjadi sangat rendah karena adanya ion-ion $\mathrm{Na}^{+}$dan $\mathrm{Cl}^{-}$. Semakin tinggi larutan garam menjadikan daya serap larutan garam hidrogel menjadi semakin menurun (Nasir, 2010).

\section{Uji FTIR Hidrogel Komposit}

Spektrum FTIR gelatin, kaolin, dan hidrogel komposit, masing-masing disajikan pada Gambar 4, 5, dan 6. Daerah dengan panjang gelombang $1000-650 \mathrm{~cm}^{-1}$ disebut daerah sidik jari dan sangat sulit untuk menganalisa jenis ikatannya. Daerah ini biasanya mengandung absorban yang sangat kompleks. Keadaan ini disebabkan seluruh jenis vibrasi bending molekul menyerap pada daerah sidik jari tersebut (Dachriyanus, 2004).

Gambar 4 menunjukkan bahwa gelatin memiliki gugus fungsi $\mathrm{NH}$ dan $\mathrm{OH}$ yang terletak pada daerah bilangan gelombang $3085 \mathrm{~cm}^{-1}$ dan dikonfirmasi ulang oleh puncak $3431 \mathrm{~cm}^{-1}$. Gelatin juga mengandung gugus fungsi $\mathrm{COOH}, \mathrm{C} \equiv \mathrm{N}$, $\mathrm{C}=\mathrm{O}$, dan $\mathrm{CH}$ yang masing-masing terletak pada daerah panjang gelombang $2928 \mathrm{~cm}^{-1}, 2144 \mathrm{~cm}^{-1}$, $1654 \mathrm{~cm}^{-1}$, dan $1450 \mathrm{~cm}^{-1}$ yang dikonfirmasi ulang oleh puncak $1402 \mathrm{~cm}^{-1}, 1402 \mathrm{~cm}^{-1}, 1384 \mathrm{~cm}^{-1}$, serta $1344 \mathrm{~cm}^{-1}$. Gugus hidrofilik reaktif pada hidrolisat kolagen termasuk gelatin adalah amino $\left(-\mathrm{NH}_{2}\right)$, hidroksil (-OH-), imino (-NH-), dan karboksil (-COOH) (Purba et al., 2018).

Gambar 5 menunjukkan bahwa kaolin yang digunakan memiliki gugus fungsi $\mathrm{OH}$ terletak pada daerah bilangan gelombang $3452 \mathrm{~cm}^{-1}$ dan dikonfirmasi ulang oleh puncak $3674 \mathrm{~cm}^{-1}$. Gugus fungsi $\mathrm{COOH}$ dari kaolin terletak pada daerah panjang gelombang $2823 \mathrm{~cm}^{-1}$ dan dikonfirmasi ulang oleh puncak $2923 \mathrm{~cm}^{-1}$, serta gugus fungsi dan $\mathrm{C}=\mathrm{O}$ terletak pada daerah panjang gelombang $1880 \mathrm{~cm}^{-1}$ dan dikonfirmasi ulang oleh puncak $1636 \mathrm{~cm}^{-1}$.

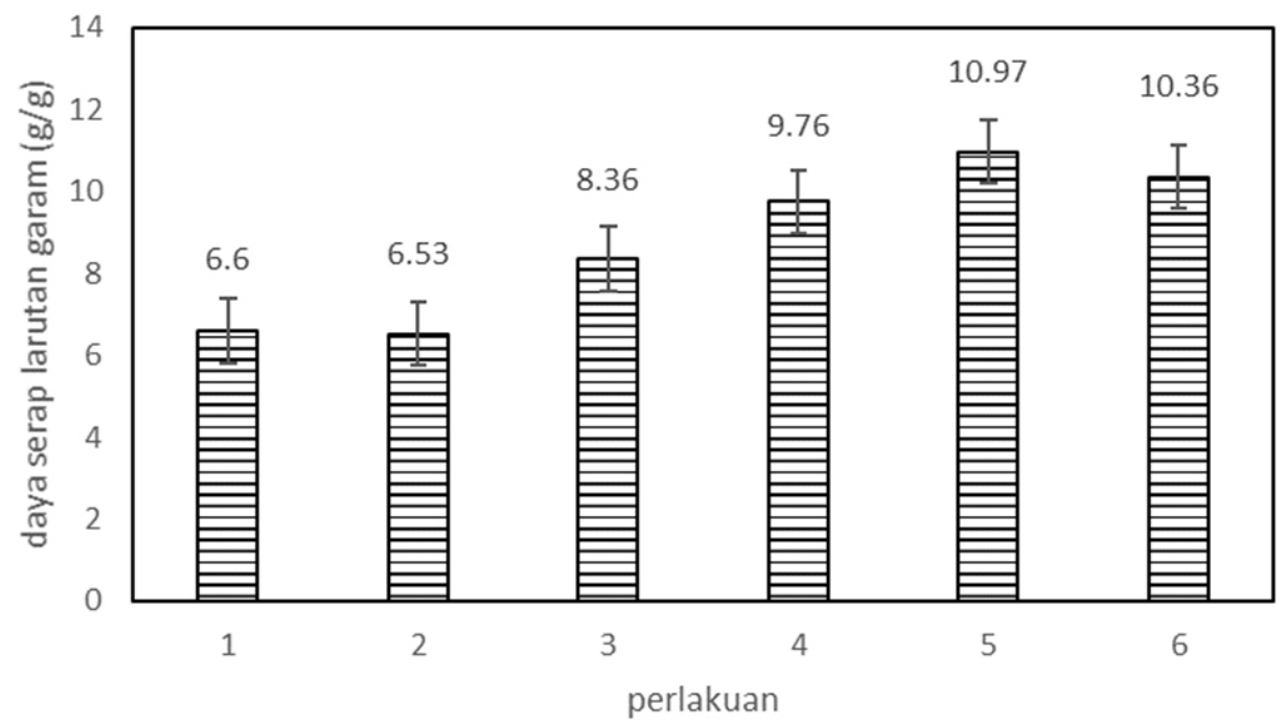

Gambar 3. Pengaruh kaolin dan MBA terhadap daya serap larutan garam hidrogel komposit. 
Gambar 6 mengindikasikan bahwa puncak serapan hidrogel komposit hasil sintesis dari gelatin asam akrilat dan kaolin mengalami pergeseran dari gelatin maupun kaolin. Pergeseran puncak serapan terjadi pada gugus fungsi $\mathrm{OH}$ yang bergeser pada daerah bilangan gelombang $3443 \mathrm{~cm}^{-1}$. Gugus fungsi $\mathrm{C}=\mathrm{O}$ hidrogel bergeser menjadi pada daerah panjang gelombang 1638 $\mathrm{cm}^{-1}$ dan dikonfirmasi ulang oleh puncak lain 1560 $\mathrm{cm}^{-1}$ dan $1540 \mathrm{~cm}^{-1}$. Gugus fungsi $\mathrm{CH}$ hidrogel bergeser menjadi pada daerah panjang gelombang $1459 \mathrm{~cm}^{-1}$ dan dikonfirmasi ulang oleh puncak lain $1405 \mathrm{~cm}^{-1}, 1385 \mathrm{~cm}^{-1}$, serta $1316 \mathrm{~cm}^{-1}$. Pergeseran puncak serapan tersebut menunjukkan terjadinya cangkok silang (grafting) gelatin-g-asam akrilat dan kaolin. Oleh karena gelatin berasal dari produk samping industri penyamakan kulit, maka pada penelitian ini telah berhasil dibuat absorben polimer hidrogel komposit berbasis gelatin produk samping industri penyamakan kulit.

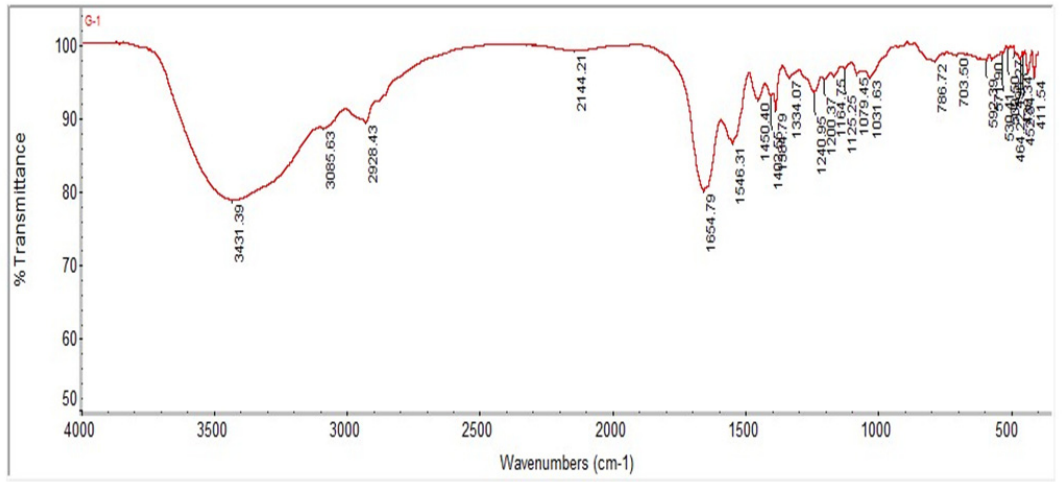

Gambar 4. Spektrum FTIR gelatin.

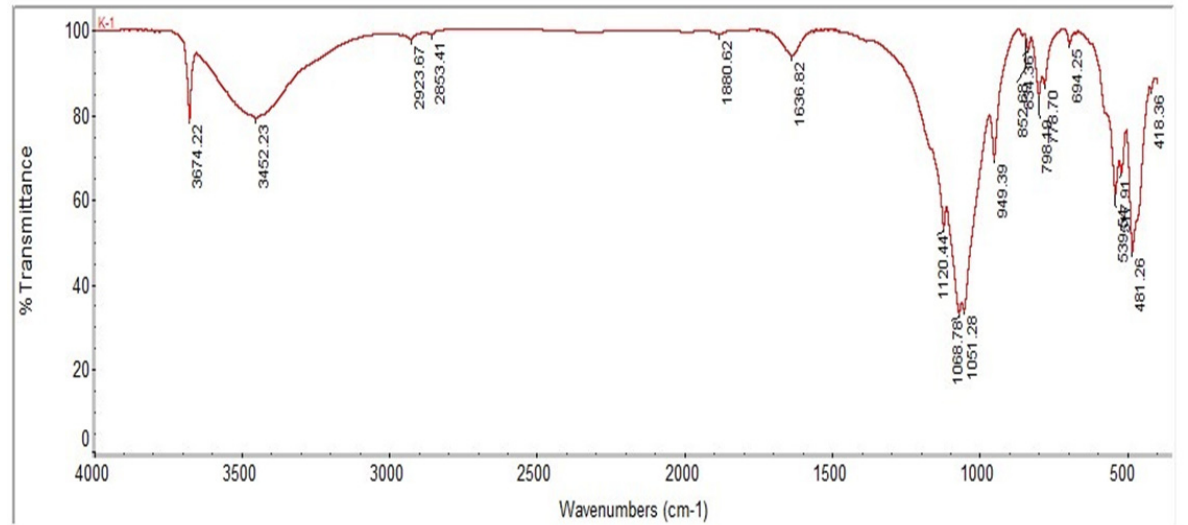

Gambar 5. Spektrum FTIR kaolin.

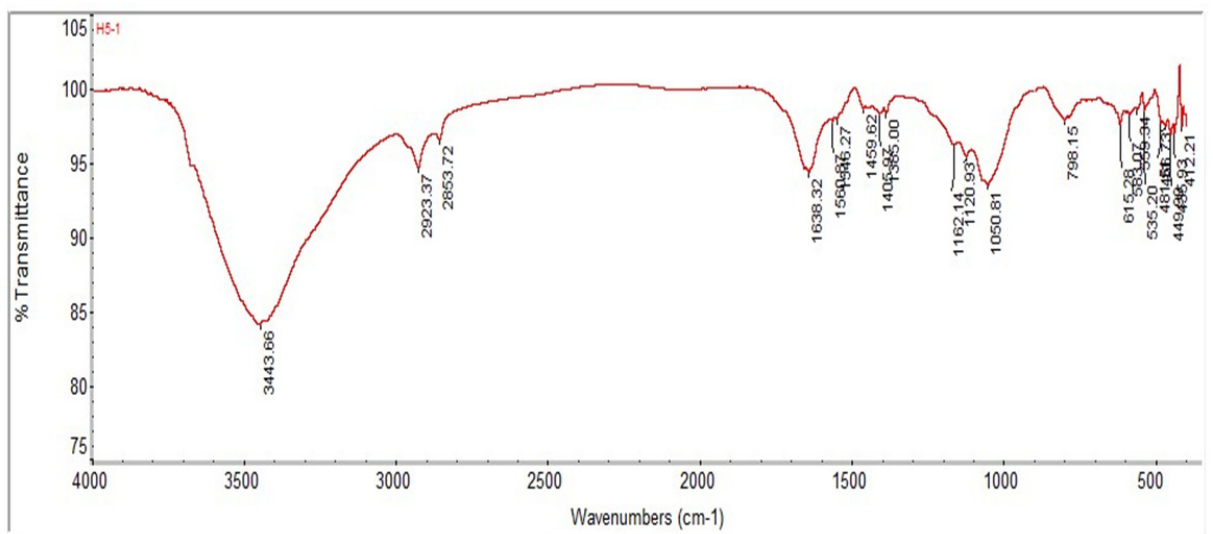

Gambar 6. Spektrum FTIR hidrogel komposit perlakuan 5. 


\section{KESIMPULAN}

Daya serap air hidrogel komposit yang dihasilkan dari penggunaan MBA 0,6 g lebih rendah apabila dibandingkan dengan penggunaan MBA 1,0 g. Daya serap air hidrogel komposit mengalami peningkatan sampai pada penambahan kaolin sebanyak 8 g. Daya serap hidrogel komposit terhadap air dan larutan garam yang paling tinggi masing-masing adalah $26,28 \mathrm{~g} / \mathrm{g}$ dan $10,97 \mathrm{~g} / \mathrm{g}$ dihasilkan dari perlakuan penggunaan MBA $1 \mathrm{~g}$, kaolin $8 \mathrm{~g}$, dan gelatin $4 \mathrm{~g}$ per $40 \mathrm{~g}$ asam akrilat. Analisis FTIR menunjukkan bahwa absorben polimer hidrogel komposit berhasil disintesis menggunakan bahan baku gelatin dari produk samping industri penyamakan kulit, asam akrilat, dan kaolin menggunakan cross-link agent MBA dan inisiator kalium persulfat.

\section{UCAPAN TERIMA KASIH}

Terima kasih kami ucapkan kepada Kepala Balai Besar Kulit, Karet dan Plastik, serta semua pihak yang terlibat dalam penelitian ini.

\section{DAFTAR PUSTAKA}

Ahmed, E. M. (2015). Hydrogel: Preparation, characterization, and applications: A review. Journal of Advanced Research, 6(2), 105-121. https://doi.org/10.1016/j.jare.2013.07.006

Anah, L., \& Astrini, N. (2015). Sintesa dan karakterisasi hidrogel super absorben polimer (SAP) berbasis selulosa menggunakan crosslinking agent watersoluble carbodiimide (WSC). Jurnal Selulosa, 5(1), 1-6. https://doi.org/10.25269/jsel.v5i01.73

Astrini, N., Anah, L., \& Haryono, A. (2016). Pengaruh metilen bisakrilamid (MBA) pada pembuatan superabsorben hidrogel berbasis selulosa terhadap sifat penyerapan air. Jurnal Kimia Kemasan, 38(1), 15-20. https://doi.org/10.24817/jkk.v38i1.1974

Baek, K., Clay, N. E., Qin, E. C., Sullivan, K. M., Kim, D. H., \& Kong, H. (2015). In situ assembly of the collagen-polyacrylamide interpenetrating network hydrogel: Enabling decoupled control of stiffness and degree of swelling. European Polymer Journal, 72, 413-422. https://doi.org/10.1016/j. eurpolymj.2015.07.044

BSN (Badan Standardisasi Nasional). (1995). SNI 013735-1995 Mutu dan cara uji gelatin. Jakarta, Indonesia: BSN.

BSN (Badan Standardisasi Nasional). (2015). SNI 8206:2015 Superabsorbent polymer. Jakarta, Indonesia: BSN.

Chauhan, K., \& Chauhan, G. S. (2010). Separation of uranyl ions on starch-based functional hydrogels: Mechanism and kinetics. Separation Science and Technology, 46(1), 172-178. https://doi.org/10.10
80/01496395.2010.484005

Dachriyanus. (2004). Analisis struktur senyawa organik secara spektroskopi. Padang, Indonesia: LPTIK Universitas Andalas.

Dian, P. P., Darmawan, Erizal, \& Tjahyono. (2012). Isolasi dan sintesis gelatin sisik ikan kakap putih (Lates calcarifer) berikatan silang dengan teknik induksi iradiasi gamma. Jurnal Sains Materi Indonesia, 14(1), 40-46. https://doi.org/10.17146/ jsmi.2012.14.1.4639

Fathima, N., Rao, R., \& Nair, B. U. (2012). Tannery solid waste to treat toxic liquid wastes: A new holistic paradigm. Environmental Engineering Science, 29(6), 363-372. https://doi.org/10.1089/ ees.2010.0445

GMIA. (2019). Gelatin handbook. USA: Gelatin Manufacturers Institute of America.

IULTCS. (2018). IUE 2 - Recommendations for tannery solid by-product management. Muttenz, Switzerland: International Union of Leather Technologists and Chemists Society.

Jakhar, J. K., Reddy, A. D., Maharia, S., Devi, H. M., Reddy, G. V. S., \& Venkateshwarlu, G. (2012). Characterization of fish gelatin from Blackspotted Croaker (Protonibea diacanthus). Archives of Applied Science Research, 4(3), 1353-1358.

Jing, G., Wang, L., Yu, H., Amer, W. A., \& Zhang, L. (2013). Recent progress on study of hybrid hydrogels for water treatment. Colloids and Surfaces A: Physicochemical and Engineering Aspects, 416, 86-94. https://doi.org/10.1016/j. colsurfa.2012.09.043

Khan, M., \& Lo, I. M. C. (2017). Removal of ionizable aromatic pollutants from contaminated water using nano $\gamma-\mathrm{Fe}_{2} \mathrm{O}_{3}$ based magnetic cationic hydrogel: Sorptive performance, magnetic separation and reusability. Journal of Hazardous Materials, 322(Part A), 195-204. https://doi.org/10.1016/j. jhazmat.2016.01.051

Khasanah, I. S. (2013). Sintesis sellulosa-gpoliakrilamida melalui teknik kopolimerisasi cangkok dan taut-silang (Skripsi). Institut Pertanian Bogor, Indonesia.

Li, Y., Huang, G., Zhang, X., Li, B., Chen, Y., Lu, T., Lu, T. J., \& Xu, F. (2012). Magnetic hydrogels and their potential biomedical applications. Advanced Functional Materials, 23(6), 660-672. https://doi. org/10.1002/adfm.201201708

Mariod, A. A., \& Fadul, H. (2013). Review: Gelatin, source, extraction and industrial applications. Acta Scientiarum Polonorum Technologia Alimentaria, 12(2), 135-147.

Nasir, M. (2010). Sifat daya serap air dan stabilitas penyerapan air hidrogel polimer komposit. Jurnal Kimia Terapan Indonesia, 12(2), 79-83.

Novi, Y., Zaharah, T. A., \& Destiarti, L. (2016). Sintetis dan karakterisasi membran komposit kitosan- 
kaolin. Jurnal Kimia Khatulistiwa, 5(4), 47-56.

Parparita, E., Cheaburu, C. N., Pațachia, S. F., \& Vasile, C. (2014). Polyvinyl alcohol/chitosan/ montmorillonite nanocomposites preparation by freeze/thaw cycles and characterization. Acta Chemica Iasi, 22(2), 75-96.

Purba, F., Suparno, O., Suryani, A., \& Fatimah, I. (2018). Hidrolisat kolagen dari limbah padat kulit samak sebagai coating superabsorbent pada pupuk lambaturai: Sebuah literatur review. Jurnal Teknologi Industri Pertanian, 28(1), 82-93. https:// doi.org/10.24961/j.tek.ind.pert.2018.28.1.82

Rahmawati, D., Sugihartono, \& Sutyasmi, S. (2016). Pemanfaatan limbah trimming kulit pikel sebagai sumber gelatin tipe B melalui pencucian menggunakan drum berputar. Jurnal Riset Teknologi Industri, 10(2), 127-135.

Sadeghi, M., \& Heidari, B. (2011). Crosslinked graft copolymer of methacrylic acid and gelatin as a novel hydrogel with $\mathrm{pH}$-responsiveness properties. Materials, 4(3), 543-552. https://doi.org/10.3390/ ma4030543
Soleimani, F., Sadeghi, M., \& Shahsavari, H. (2012). Graft copolymerization of gelatin-g-poly (acrylic acid-co-acrylamide) and calculation of grafting parameters. Indian Journal of Science and Technology, 5(2), 2041-2046.

Suryani, N., Sulistiawati, F., \& Fajriani, A. (2009). Kekuatan gel gelatin tipe B dalam formulasi granul terhadap kemampuan mukoadhesif. Makara, Kesehatan, 13(1), 1-4.

Verma, M. K., Pandey, P., \& De, N. (2017). Characterization of water retention and release capacity ofinnovativenanoclay polymercomposite superabsorbent. Journal of Pharmacognosy and Phytochemistry, 6(6S), 42-48.

Zafar, S. (2012). Wastes generation in tanneries. https://www.bioenergyconsult.com/waste-fromtanneries/, diakses 13 Januari 2020.

Zohuriaan-Mehr, M. J., Omidian, H., Doroudiani, S., \& Kabiri, K. (2010). Advances in non-hygienic applications of superabsorbent hydrogel materials. Journal of Materials Science, 45, 5711-5735. https://doi.org/10.1007/s10853-010-4780-1 
